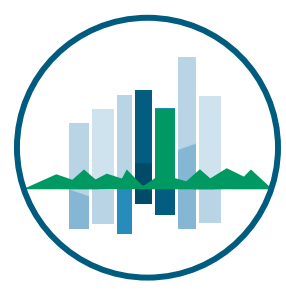

True Smart and Green City?

8th Conference of the

International Forum on Urbanism

Conference Proceedings Paper

\title{
Social and Governance Innovations for Enabling Place-Based Sustainability Transitions: The Case of Village Communities in Seoul
}

\section{Marc Wolfram}

Yonsei University, Dep. of Urban Planning and Engineering, Seodaemun-gu, Sinchon-dong, Yonsei-ro 50, 120-749 Seoul, South Korea; E-Mail: m.wolfram@yonsei.ac.kr, Tel.: +82 22123 5895; Fax: +82 2 393-6298

\begin{abstract}
This paper discusses current efforts of the city of Seoul to grapple with some of its most pressing sustainability problems through conjoint social and governance innovations. Drawing on pertinent strands of urban-, transition-, and resilience-studies, it reviews the design and implementation of activities aimed at establishing a self-organizing social innovation ecosystem nurtured by place-based networks at neighborhood scale ("village communities"), and reflects on their potential to effectively enable wider sustainability transition dynamics.
\end{abstract}

Keywords: sustainability transitions; urban governance; social innovation; village community; capacity building

\section{Introduction}

Cities are critical hotspots for sustainability transitions. This is not only due to their quantitative impacts in a quickly urbanizing world, but more importantly regarding their qualitative influence as 'role models' and incubators of societal change [1,2]. It is essentially urban patterns of cultural practice, social interaction, as well as production and consumption that drive global flows of people, materials and information. With a view to the complexity and urgency of persistent sustainability problems relating to environmental change, social injustice and economic restructuring, cities are thus challenged to develop novel responses that can overcome the limitations of piecemeal and incremental improvement: The quest 
is for transformative approaches that may enable, trigger, accelerate and scale-up radical sustainability innovations within and across multiple areas of life [3,4].

Research that has engaged with transition dynamics in relation to the local scale has so far emphasized three basic levers of change (see section 2): 1) Policy-driven (multi-level) governance shifts, 2) community-driven grassroots innovations, and 3) broader capacity-building processes supported by diverse stakeholders. All of these levers rely on particular forms of agency and social interaction, and may imply a significant potential for synergy in case of their interconnection $[5,6]$. Their coincidence under conditions of place thus raises crucial issues of interest for urban sustainability transitions, but is not well understood to date.

Especially the direct encounter between purposive forms of innovation in urban governance, capacity building and community practice forms a blind spot here: What are the shared objectives and strategies pursued, how does a coordination occur, and what conditions their success or failure? This is not only a matter of conflicting interests and power positions, ranging from urban (growth) regimes to grassroots movements. It also asks for differences and similarities regarding the socio-technical systems (STS) and social-ecological systems (SES) addressed by them. Moreover, there is a constitutive but often disregarded role for urban place and the built environment in this, i.e. not only selected STS or SES components: How does the spatial coincidence of diverse networks and flows and their articulation in concrete urban places affect the innovation needs, priorities and resistances in a particular city? This coincidence may represent both an opportunity, but also a barrier for simultaneously dealing with multiple system transformations [7].

Starting from these considerations, this paper will therefore discuss ongoing social and governance innovations in Seoul, the South Korean capital. The case provides for a pertinent example of novel strategies and approaches that aim to leverage 'top-down' and 'bottom-up' innovation dynamics in a given urban context. It is also of high interest with a view to the sustainability impacts of urban development in both developed and developing Asia [8]. Section 2 lays out the conceptual and analytical framework for the case study, and details the methods used. Section 3 synthesizes the relevant conditions and changes observed in Seoul, which are then reviewed in section 4 in the light of the analysis criteria adopted. Finally, some more general conclusions regarding urban transition research and policy are drawn in section 5 .

\section{Cities and transformative change}

Within transition studies, the number of contributions addressing the role of the local scale as a catalyst for sustainability transitions is growing quickly [9-15]. However, this does not always include an explicit concern for 'the urban' and recognition of its particularities, nor an orientation at urban policy making or planning intervention. Without an explicit reference to urban studies, the local scale is also often discussed in more general terms, for instance as a site of everyday-life practices and social innovation, and/or as an articulation of particular STS or SES (energy, water, etc.). Correspondingly, diversity exists in the identification of the relevant landscape pressures such as resource scarcity, environmental risks or deficits in terms of quality of life, which in turn implies emphasis on different stakeholders responding to them (e.g. local or regional governments, infrastructure providers, grassroots movements, communities). 
In order to identify a set of criteria that especially cities should meet to successfully enable, initiate and manage sustainability transitions, three strands of research dealing with transformative change at the local scale appear to be particularly useful here, respectively focusing on 1) urban infrastructure governance, 2) social innovations, and 3) social-ecological resilience. They represent complementary, yet also interconnected viewpoints regarding the assumed drivers of change, the agency and dynamics created by them, and the role of urban space and place in this.

\subsection{Innovation and experiments in urban infrastructure governance}

The question whether and how cities can actually shape transitions has so far been raised most explicitly by studies focusing on the governance of urban infrastructures [16]. Responding to the twin challenge of peak oil and climate change, urban policy has increasingly embraced "low carbon" futures over the past decade. This reflects the vital need for cities to secure long-term access to and management of resources by decarbonizing their key infrastructures for energy, water, waste and transport [17-19].

Drawing on the multi-level-perspective (MLP) [20], the analytical focus has thus been on the governance innovations created in order to transform the corresponding STS [21,22]. Especially local and other tier government agencies, industry and providers, but partly also civil society organizations engage in new forms of interaction that involve practical experimentation and learning mechanisms (organizational and institutional), as well as vision development and strategy making. The combination of these characteristics is particularly relevant for managing transformative change [23]. Moreover, to create shared discourses, trust and durable working relations, stable intermediaries have been recognized to be critical, i.e. organizations newly formed or taking a novel role in managing expectations, interests and joint action between the relevant stakeholders. But also individuals acting as border-crossers or institutional entrepreneurs appear to play a vital role in such processes for promoting and articulating alternative system configurations [12,24-26].

\subsection{Emerging social innovations and grassroots niches}

To distinguish such policy-driven governance innovations from more community-based sociotechnical change, the notion of 'grassroots niches' has been coined [27]. This recognizes social practices as an equally basic condition for system transitions [28]. Grassroots niches focus on social needs instead of established STS, and are therefore rather diverse in scope and scale. This also enables them to conceive of newly integrated and cross-domain solutions (e.g. sharing practices, alternative currencies). They rely on a vast range and depth of local knowledge to create innovative solutions that are well embedded. Therefore, grassroots also tend to primarily generate direct benefits for the community since this plays a key motivational role (e.g. in terms of identity, self-expression, recognition, belonging or aspirations). However, these may in turn influence wider STS transformations [29].

Studies have therefore explored the potential for mainstreaming grassroots innovations through nicheregime interactions, zooming in on the role of practical know-how, physical activities and cultural meanings. Drawing on strategic niche management [30], three factors have been confirmed empirically that appear to determine a successful development and diffusion of grassroots niches [31-33]: 1) Expectations of what the innovation shall achieve need to be widely shared among participants and stakeholders, as well as specific and realistic; 2) Networking is needed beyond the community to bring 
in the diverse resource types required for implementation (human, scientific, technological, organizational, institutional and financial) and to broaden support for the innovation's objectives; 3) Learning should be experiential and occur in the social context of communities, organizations or institutions, thereby changing actor preferences and practices.

The first two factors are particularly challenging for grassroots. Expectations and actual delivery often tend to fall apart due to a lack of skills and resources. In turn, networking is limited since grassroots usually constitute an antithesis to regime actors and practices, and/or operate more self-referential if strongly rooted in a particular place. Social innovation studies equally recognize these challenges and point to the need for active empowerment as a necessary response [34-36]. By providing direct material or immaterial support for those ultimately affected (e.g. through participation, training, subsidy), communities should be enabled to improve their autonomy, engagement and resource basis. This also addresses change in community-level social relations since it is here that roles, identities and practices have to be reconfigured [37,38].

\subsection{Adaptive and transformative capacities of urban stakeholders}

While the above two research strands both aim to explore the characteristics of positive transitions in STS, resilience studies have started to engage with responses to negative transitions, failures or disasters in social-ecological systems instead. This perspective emphasizes global environmental change as a key driver since it strongly affects local vulnerabilities. Drawing on the adaptive renewal cycle [39], the focus has thus been on what strengthens or undermines the capacity of urban stakeholders to reconfigure SES through self-organization [40-43]. Most importantly, based on the concept of panarchy this implies to account for scale interdependencies (local to global) and different temporalities (fast/slow) in this, which may curb or accelerate transformation [44].

To stabilize desirable SES functions and identities, responses have thus been primarily conceived in terms of building adaptive capacity. Yet, there is an increasing concern for transformative capacity building under conditions of thoroughly unsustainable performance in order to seize opportunities for system innovation $[45,46]$. Both approaches entail to enhance diversity (of knowledge, organizations, partners, instruments, methods, etc.) and redundancy (overlapping ends, but different means), and to foster collective learning-by-doing (e.g. through participation, training, networking, collaborative governance).

Resilience studies have thus identified basic requirements for enabling urban transitions that partly coincide with those discussed in the STS literature, especially with a view to multi-level governance, experimentation and learning-by-doing. But these are seen as embedded and encompassing processes both at a community and a wider societal scale, thus linking social and governance innovations within a social-ecological landscape. Moreover, particular emphasis is put on the need to foster the diversity and redundancy of solutions through self-organization, rather than management. Therefore, capacity building for urban stakeholders turns out to be the essential response strategy to facilitate adaptation, reconfiguration or transformation [47]. 


\subsection{Analysis framework and case study methods}

Considering the above range of factors that appear to condition sustainability transition dynamics at the local scale, four broad criteria are derived here to guide the case study. They provide a framework for analyzing the conception and implementation of urban policies and practices regarding their suitability for effectively driving transformative change. Based on the research strands discussed, all criteria are concerned with embedded stakeholder interactions, and are therefore also mutually enabling and reinforcing. The approach embraces an understanding of cities as local manifestations of multiple SES and STS in order to account for diverse types of drivers and innovation dynamics. In addition, it also recognizes the vital role of place and the built environment in the creation of novel responses to urban sustainability challenges. The four criteria are underpinned by a set of research questions that have been used to explore current innovation activities in Seoul (Table 1).

For data collection and analysis, various methods including web and document reviews, site visits, participant observation, as well as in-depth interviews with 21 selected individuals have been employed. These tasks were realized between June 2013 and February 2015 and involved all key stakeholders including different local government departments, community activists, NGOs, private companies, research institutes and intermediary organizations. This provided the required qualitative and quantitative data to answer the above questions. In order to calibrate the final interpretations and conclusions, these have also been discussed in a focus group with 5 key stakeholder representatives.

Table 1. Framework and criteria for analyzing the transformative potential of stakeholder responses to key urban sustainability challenges

\begin{tabular}{|c|c|c|}
\hline Conditions & Criterion & Questions \\
\hline \multirow{4}{*}{ 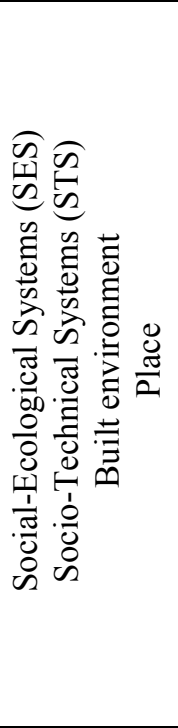 } & $\begin{array}{l}\text { Visions and } \\
\text { social needs }\end{array}$ & $\begin{array}{l}\text { What are the key drivers of policies and initiatives (e.g. } \\
\text { environmental change, social cohesion, quality of life)? How } \\
\text { do they relate to real social needs? What are the respective } \\
\text { visions and expectations formulated by different } \\
\text { stakeholders, and how far are they shared? }\end{array}$ \\
\hline & $\begin{array}{c}\text { Governance and } \\
\text { social relations }\end{array}$ & $\begin{array}{l}\text { What are the governance innovations and networking } \\
\text { activities introduced in pursuit of the visions? What forms of } \\
\text { agency are involved, and what forms of intermediation? How } \\
\text { do social relations at community level become modified? }\end{array}$ \\
\hline & $\begin{array}{l}\text { Empowerment } \\
\text { and self- } \\
\text { organization }\end{array}$ & $\begin{array}{l}\text { How do actions contribute to empower civil society } \\
\text { stakeholders and grassroots niches? How is the self- } \\
\text { organizing capacity of stakeholders supported? How do these } \\
\text { actions affect the emergence, diversity and redundancy of new } \\
\text { solutions? }\end{array}$ \\
\hline & $\begin{array}{c}\text { Experimentation } \\
\text { and learning }\end{array}$ & $\begin{array}{l}\text { What kind of learning mechanisms, methods and formats have } \\
\text { been developed at individual, organizational and institutional } \\
\text { levels? What is the role of experimental action and learning- } \\
\text { by-doing in this? }\end{array}$ \\
\hline
\end{tabular}

\section{Village communities and social innovation policies in Seoul}

With its 10 Mio. inhabitants, Seoul undoubtedly represents a 'Megacity' - a classification which often implies that attention is drawn to the large scale of problems and solutions in terms of urban development. Yet, over the past few years, it is neighborhoods that have come to take a central role on 
the agenda of public policy and civil society stakeholders alike: So called 'village communities' i.e. place-based, self-organizing citizen networks that are only loosely delimited by their socio-spatial identity, have started to spread out through the metropolitan area and its 25 autonomous districts, providing a growing pool of diverse social innovations.

This section synthesizes this complex process by providing a narrative focused on drivers, agency, institutions and outcomes, thereby cutting across the above four analysis criteria. It first introduces to the urban context and its sustainability challenges with a view to landscape pressures and regime failures that inform actor visions and expectations. Second, it outlines emergent responses developed in terms of urban village communities and related governance innovations. Third, it summarizes the main outcomes so far, recognizing patterns and trends of social innovation in practice.

\subsection{Sustainability challenges for Seoul}

Looking at key indices for South Korea quickly reveals that the country's fast economic development has come at a considerable social and ecological price: Per capita GHG emissions and energy consumption (85\% imported fossil fuels) are very high and expected to further rise towards 2030 [48] (IEA 2012). While the population is rapidly shrinking, ageing and individualizing, single-person households and per capita living space are steadily increasing [49]. Global ranks regarding gender equity (100th), overall happiness (60th), length of working hours ( $1^{\text {st }}$ in OECD) and the $2^{\text {nd }}$ highest suicide rate worldwide shed light on severe social problems [50-52].

Since the 1960s, urban development has significantly contributed to this situation, and Seoul is an outstanding example for this. Based on top-down policy making and planning without noteworthy participation of civil society, programs of "redevelopment" were pushed through to accommodate fast growth and urban migration (from 2.5Mio inhabitants in 1960 to 10Mio in 2015). Densely packed highrise apartment blocks expanded from 24.000 units in 1970 to 1.5 Mio units in 2010, either by demolishing existing city districts or by spreading into the periphery. Real estate prices rose much faster than incomes and fostered the influence of (a few large) property owners, as well as new socio-spatial divides between new and old fabrics [53]. The latter were largely left to market forces, thus fostering speculation and/or urban decay. Until very recently, more cautious forms of urban regeneration have not been trialed at all [54].

The sustainability implications of this urbanization pattern are manifold. Today, over $70 \%$ of Seoul's inhabitants live in apartments - a homogeneous and inflexible housing typology focused on the traditional family unit. A clear-cut segregation correlates building location, date of construction and socio-economic status of inhabitants, reinforced by the ensuing spatial differentiation of functions. Therefore, household fluctuation is very high (17.4\% move every year). This has steadily weakened social cohesion within and between neighborhoods, and undermined citizens' sense of ownership and responsibility for built environs and green spaces [55]. The practice of "redevelopment" has also constantly reduced the availability and functionality of the city's green infrastructure, and heavily fostered car-dependent lifestyles. In addition, developers have only lately started to adopt green building standards. Apartments and older fabrics both display characteristics regarding materials, energy, water, noise and green space that imply a rather poor environmental performance. 


\subsection{Origins of urban village communities}

The recent turn towards community development in Seoul has its antecedents in state policies, as well as in local grassroots initiatives. Both are based on the spatial concept of "Maeul" i.e. village. Since 2007 several minor national "village" subsidies have been devised by different ministries, supporting social interaction at a neighborhood scale for creating e.g. local enterprises, better housing quality or green infrastructures - yet without forming a coherent framework (Seoul Institute, 2012). While each instrument pursues different objectives, they all draw on communities as a resource for solving selected social, economic or environmental problems. Also at the local level, "villages" became increasingly virulent in urban politics from 2009, addressing especially issues of transparency in the maintenance of apartment complexes (usually controlled by powerful housing corporations).

This orientation of state policies towards urban "villages" mirrors developments already under way in civil society since the early 1990's. By then, activists increasingly turned towards local community building as an effective response to pressing social and ecological problems, thus filling gaps in policy and institutions. The notion of "village making" was adopted by citizen-driven initiatives emerging in different Seoul districts, and first guidance for establishing "ecological villages" within cities was published [56,57].

A particularly influential case of autonomous village community development is Sungmisan, a small neighborhood in northwest Seoul. In 1994, some 20 households created Korea's first kindergarten cooperative here, next to an urban forest hill (Sungmisan). Since then this community has launched a wide range of initiatives: A consumer cooperative (2001), a community center (2003), an alternative school (2004), and over 20 social enterprises employing about 150 residents (from stores, restaurants and workshops to care services and a co-housing company). Today, Sungmisan village represents a social network of roughly 5.000 households. Its consumer cooperative has an annual turnover of $€ 3.3$ Mio, and it receives 4-5000 visitors every year that come for information purposes [58,59].

Sungmisan village has crucially informed the design of current social innovation policies in Seoul in various ways: First, it is essentially driven by social needs as people strive to improve the quality of life for their children and themselves. This has however led to also embed ecological values in a range of place-based socio-economic activities (e.g. gardening, organic food, building retrofitting). Second, the community has always relied on learning-by-doing, constantly seeking new solutions in multiple domains of everyday life. Since this also included failures, the risks and potentials of an experimental approach for driving change could be acknowledged on the basis of a practical example. Third, policy learning was fostered by fierce conflicts with local government in 2004 and 2010 over redevelopment projects that threatened to destroy the adjacent green space of Sungmisan. This struggle decisively helped the wider recognition of "villages" as an important resource nurtured by local identities and social bonds.

By 2010 "village community" development had thus become a central reference point both in public discourse and policy in Seoul, but despite obvious relations, both practices still remained largely separate. 


\subsection{From grassroots niches to social innovation governance}

Between 2011 and 2013, a new policy and governance framework for village communities has been developed and implemented in Seoul. Its stated primary objective is to "grow and diversify village communities for achieving autonomy and improving democracy" [60], targeting their maturity and selforganization by 2017 [49]. This innovation relies on five conditions that will be briefly sketched in the following: Political leadership, organizational change, cooperation culture, regulatory frame, and new intermediaries.

In October 2011, Park Won Soon was elected mayor - a political landslide for Seoul. Park has a strong record in institution-building for social justice at the national level, as well as close ties to international networks in this field. His political agenda is centered on empowerment and justice [61]. Yet, in line with citizen's high expectations for policy change (ibid. p.33), he also launched major initiatives for energy efficiency, a social economy, a sharing economy, participatory budgeting and open government. Hence, the renewed policy concern for social practices at the neighborhood scale was crucially driven by political leadership and addresses a range of key policy objectives - including the urgent need to reduce the city's rapidly growing welfare expenses.

Within Seoul Metropolitan Government (SMG - the local authority responsible for the Seoul metropolitan area and its 25 autonomous districts) these shifts have been prepared and supported through the creation of the "Seoul Innovation Bureau" (SIB), installed shortly after the 2011 elections. Directly adjoined to the mayor's office, this new unit was given the task to inspire and drive social and institutional innovations across departments, but also beyond the boundaries of the local authority. It's staff of around 30 was recruited mainly from civil society and private sector organizations, while lead positions also include senior government officials. This organizational change has been instrumental to effectively mediate frictions between new ideas and established routines. It was also important to establish the new cross-departmental activity of village community development within the administration, as $55 \%$ of the total SIB budget are dedicated to this.

These political and organizational shifts have accompanied the rise of a new cooperation culture, linking local government and civil society. Between 2011 and 2012 the SIB organized three major gatherings involving 50-80 grassroots activists from a variety of fields. A task force of activists was formed to elaborate the main terms and principles of a new policy oriented at "village communities". In parallel, the SMG-owned research agency "Seoul Institute" conducted a status analysis regarding existing civil society initiatives in the city to identify potential anchorage points. [49].

In August 2013 a regulatory frame was adopted by the city council, making the new forms of interaction binding for all parties ("Building a village community in Seoul"). This ordinance defines a basic governance system including the creation of a new coordinating entity, the "Village Community Support Center" (VCSC). General decisions regarding budget allocation and policy adaptations are being taken by a steering committee composed of representatives from civil society, SMG (various departments) and the VCSC [60]. An implementation plan must be drawn up by the VCSC and Seoul Institute, and revised every 2 years. In terms of orientation, the first plan posits "happiness" as the overarching aim for village development and defines an approach for supporting citizen-driven initiatives aimed at practical solutions that fulfil social needs [49]. 
Within this evolving governance system the VCSC plays a core role as an intermediary to bridge the existing gaps between civil society and local government in terms of trust, skills and language [49]. While being $100 \%$ funded by SMG, the VCSC is therefore fully independent in its operations and has been largely staffed with non-officials. Moreover, a co-founder and activist of the pioneering community Sungmisan Maeul was appointed as director. The VCSC manages the process of creating and establishing community initiatives, involving different experts, and coordinating with SMG departments. It collects proposals for new initiatives, supporting those that show the highest potentials in terms of "necessity, public benefit, feasibility, durability, creativity, participation, resources, partnership, expected results" [49]. In 2013, also district-level support entities have been created through a call for proposals, and this logic will extend further down to the boroughs in 2015. While differing in size and set-up (authority or civil-society-led, centers or networks, district or borough scale), these new entities increasingly take over support tasks from the central VCSC, which in turn may focus more on managing relations with SMG departments in the future (Fig.2).

Figure 1. Governance structure for village community development in Seoul 2014 (Source:

Author

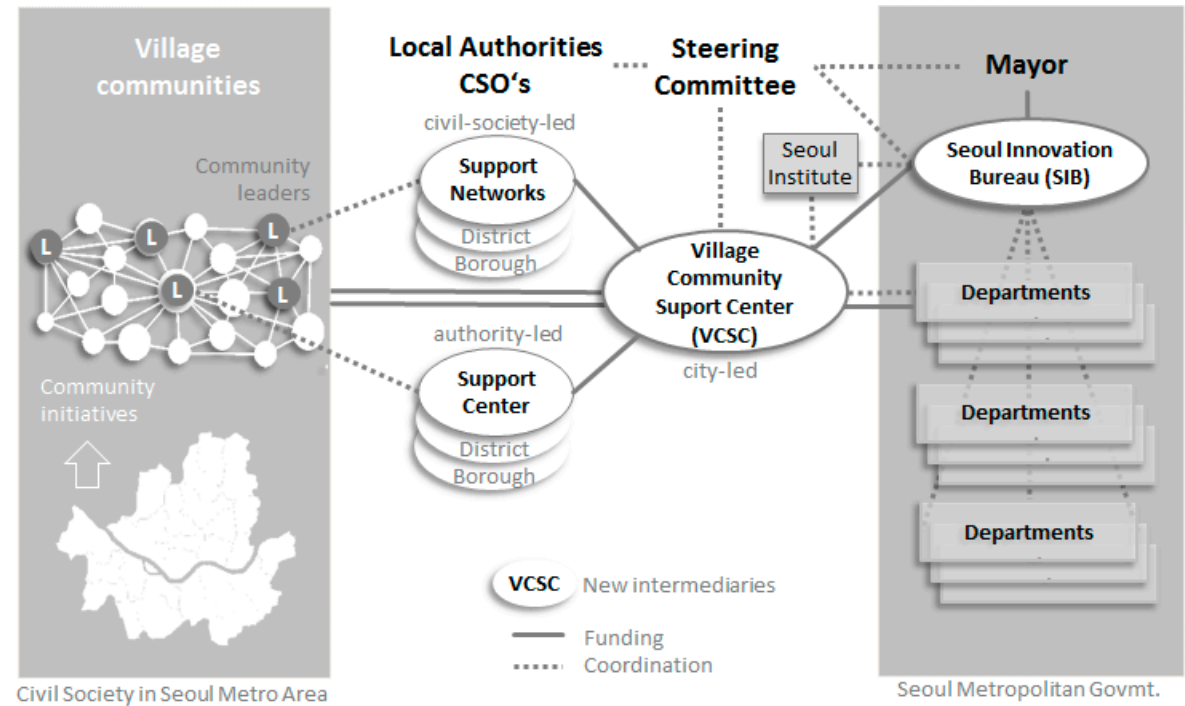

\subsection{Evolution and patterns of outcomes}

Through the approach and governance set-up described above, Seoul has seen the emergence of a plethora of diverse new village community initiatives since 2012. Some patterns and trends can be observed in this process that are relevant for enabling sustainability transitions. These concern the social needs addressed, empowerment methods and conditions, socio-spatial change and learning.

Initially, community initiatives were required to start from a given range of issues, mainly revolving around education, culture, cohesion and open place provision. Only for communities in apartment complexes there was no such specification. However, in 2013 new bottom-up categories were introduced ("open themes", "community networks"), and budget allocations for these have grown considerably (Fig.3). Facilitated through these modifications, it appears that initiatives increasingly also articulate social needs related to economic and environmental sustainability concerns e.g. regarding energy and consumption patterns (renewables, local organic food and low-carbon products, sharing), employment 
(social enterprises), green education, water usage or green infrastructures (gardening, farming) sometimes also beyond the village scale. These initiatives start to engage with wider SES and STS transitions, but this is being recognized only recently. For instance, the city's updated "sustainable energy action plan" of November 2014 now envisages coordination with energy-oriented village communities [62].

For empowering and supporting initiatives, the VCSC has applied a conceptual stage model, focused on leading activists [49]. Trainings are designed to help them meet the changing requirements in each stage (e.g. from collective decision making and conflict management towards business planning and project evaluation), thus gradually enabling self-organization. While this model has proven its effectiveness, limitations appear to lie in wider context conditions that determine its accessibility. Active community engagement is significantly constrained by long working hours, minimum wages, high real estate prices and related household fluctuation, but also by the lack of open spaces for people to meet. Hence, especially younger generations and full-time employed men are hardly involved, while the majority of community leaders are women above 40. Simultaneously, novel types of conflicts have emerged between social innovators and "conservative" residents, and between new "professional" networks and pre-existing "laymen" initiatives. Context conditions and empowerment methods have thus also fostered distinct kinds of social divides within and between neighborhoods that raise questions of leadership, representation and impact.

At the scale of the metropolitan area, these implications overlay with existing differences between districts regarding their socio-economic profile (income, education) and institutional thickness (availability of CSO's, cooperation culture). Initiatives thus largely differ from place to place not only in terms of their activity profile (social needs addressed), but also regarding their capacity to sustain activities and potentially engage in wider change.

These issues become particularly important with a view to the lack of a systemic monitoring and evaluation approach. While the performance of individual initiatives has been regularly evaluated by the SIB, the methods and purpose of this continues to be disputed between communities and the SIB, leading to demands for more "self-evaluation", wider exchange and knowledge transfers.

Figure 2. Spatial distribution and budget evolution of new village community initiatives in Seoul Metropolitan Area 2012-2014 (Data: VCSC 2014)

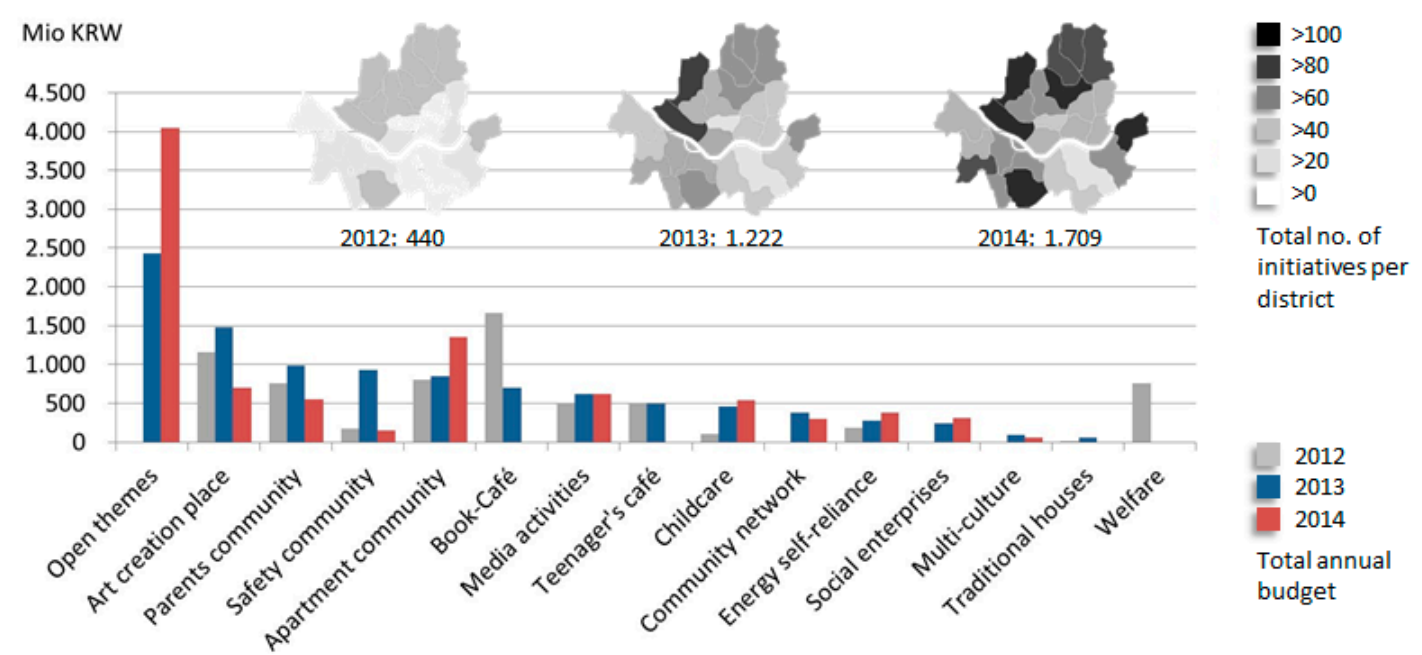




\section{Towards place-based sustainability transitions in Seoul?}

As the previous sections have illustrated, the case of village communities and social innovation governance in Seoul shows a significant potential in terms of enabling transformative change for sustainability, but also reflects critical deficits in this regard. Referring to the four criteria adopted above, this section synthesizes the key strengths and weaknesses. In so doing it responds to the explorative questions formulated, and points towards future issues in research and policy.

\subsection{Visions and social needs}

The innovations analyzed are not primarily driven by global environmental change and/or its economic implications for a competitive metropolis. Rather, the focus has so far been on livability at the scale of the neighborhood and a range of widely recognized social sustainability issues: education, care, safety, cohesion, identity and autonomy. These issues are strongly conditioned by the particular urban structures, designs and development dynamics in Seoul, which undermine citizens' sense of place and stable community relations. An open and inclusive policy vision has thus been formulated that posits "happiness" and place-making as key values. This has allowed to obtain wider stakeholder support and establish a shared discourse on "village communities", embracing both the diversity of existing grassroots initiatives and the various national "village community" policies - regardless of their rather different objectives.

To connect this broad vision with concrete social needs, important adjustments have been undertaken in the course of implementation. Policy has quickly moved from guiding community initiatives towards particular means and ends to open calls for proposals, requiring citizens to articulate their own needs. This bottom-up move has countered criticisms reading social innovation policies as a mere neoliberal attempt to shift responsibilities to communities and individuals. At the same time, it has considerably widened the transformative scope of initiatives and raised the corresponding expectations of stakeholders. Communities in fact increasingly address environmental change and local economies. Since their innovations provide important input for the transformation of key urban STS and SES (e.g. infrastructures, housing, mobility, green space), it becomes critical if other policies and practices will also enable community feedback (not only support) and follow up on this emerging potential.

\subsection{Governance and social relations}

A highly differentiated governance system for social innovations has been shaped in Seoul and is still in evolution. Through the initial creation of new intermediaries, this system targeted mainly two types of innovation barriers: Within local government, the SIB was designed to accommodate newcomers and create pressures for change, while also moderating between these and established interests and routines in the administration. This has crucially enabled wider ownership and the adoption of new practices. In turn, the VCSC and the district-level support initiatives were devised to build mutual trust between civil society stakeholders and authorities. Organizational independence and strategic staffing choices (bordercrossers) have turned out to be key success factors in both cases. In addition, leadership by the mayor, continuous involvement of civil society, and an agreed overall decision making structure have been equally decisive for implementation. 
These shifts in government/civil-society relations are directly linked to changes in social relations at community level as well. SMG demands, but also facilitates, the formation of new social networks and co-operations, as well as the creation of open places located within the neighborhood to physically enable the targeted interactions (e.g. community center, book café, youth club, etc.). To overcome the manifold barriers encountered in practice, the focus has been on key individuals that can provide the necessary leadership, motivation and endurance. While this has successfully helped to form a large number of place-based initiatives around shared concerns, it has equally furthered the articulation of novel conflict lines within communities that will require particular attention ('innovators' vs. 'conservators', and 'old' vs. 'new' initiatives). Moreover, regarding the growing need to link between community initiatives across the metropolitan area, and with stakeholders operating at other scales (e.g. business, industry, ministries), progress has been rather limited so far.

\subsection{Empowerment and self-organization}

Empowerment of civil society has been a central axis of the activities developed. This presupposed securing organizational stability and resource availability (financial-, human-, knowledge-) through regulation. Based on this, targeted support has been offered through seed funding, expertise and training. Also more general conditions for community autonomy have been strengthened, including skills for communication and collective decision-making, or the freedom of expression through art, cultural activity and media. However, key context constraints for wider citizen involvement have played out that would require parallel action in a number of domains with a longer time horizon (e.g. fixing rates for social housing).

Despite these limitations, the methods used have effectively multiplied the diversity and redundancy of solutions available by nurturing the ability of citizens and grassroots initiatives to realize innovative place-based practices. At the same time, they have enhanced the exploration and creation of new meanings, identities and values that can support alternative pathways - from environmental concerns to manifestations of difference in design and aesthetics in everyday life. This variety now raises questions of strategy with a view to purposefully manage successful niches, help their self-organization also for upscaling solutions, and reduce the dependence on public subsidy.

\subsection{Experimentation and learning}

The approach pursued clearly represents a place-based and unique governance experiment. Learningby-doing and adaptation have thus been principles incorporated from the outset and at all levels: Individuals, communities, CSO's, SMG departments and the new intermediaries have been challenged to trial innovative solutions and acquire the knowledge and skills required for implementation, but also to learn from their experiences and broaden the scope and impacts of their activities. Several changes in the organizational set-up of the SIB and VCSC, the shift towards open calls for proposals, and the creation of various types of support entities at district- and borough-scale all reflect social and institutional learning, in particular regarding the type of community support required.

However, the lack of a systemic evaluation and learning approach at the scale of the metropolitan area results to be particularly problematic. Current efforts are still mainly focused on justifying public expenditures on a project-by-project basis, and on promoting good practice through informational 
formats (lectures), but fail to explore larger patterns in the social innovations created. Recognizing these would however be crucial to inform strategic responses in pursuit of synergies for driving systemic change.

\section{Conclusions}

This paper has explored the emergence of village communities and social innovation governance in Seoul with a view to identify potentials and limits for enabling urban sustainability transitions. To do so, an analytical framework has been deducted from pertinent strands of urban-, transition- and resilience studies that focuses on four key criteria: 1) Visions and social needs; 2) Governance and social relations; 3) Empowerment and self-organization; and 4) Experimentation and learning. In conclusion, the empirical findings point towards the following general implications and hypotheses for transitionoriented urban policy, planning and research:

1) New forms of 'up-down governance' in cities are likely to materialize especially with a focus on social innovation - but this requires politicizing social needs. The changes observed in Seoul are essentially driven by massive deficits in terms of livability, not by the city's pressured political ecology. This has provided the necessary political leverage and leadership, but also the orientation of policy at social needs and innovation at the scale of the neighborhood. It is also on this basis that the tactical governance shifts described could be introduced, connecting grassroots with policy and thereby gradually lowering important institutional and cultural barriers to transitions in a context of authoritative steering.

2) The focus on 'villages' i.e. place-based practices, social relations, local knowledge and experimentation results to be an effective but also necessary approach for creating diversity and redundancy, and for confronting multi-regime transformations in cities. Without a given emphasis on any particular system perspective (e.g. green infrastructures, energy, food), it is the instantiation of multiple networks and flows in particular urban settings that connects between various systems of provision. Hence, the resulting variety of deeply embedded and innovative solutions forms a highly valuable resource for driving urban transitions. However, attention must be paid to the existence or emergence of barriers to involvement and more general conflict lines between different social groups.

3) The suggested conditions for enabling transformative change in cities have been confirmed to be key in the case of Seoul - but they are hardly reflected in all domains of urban development, and not all of them are met. In this regard, Seoul appears to stand at a tipping point: Despite the broad vision, cross-department constitution and diverse outcomes the approach developed still appears to be confined to the realm of 'social policy'. It is here that the existing deficits in terms of institutional learning may become critical, and more substantive power conflicts could emerge. In order to enable impacts beyond the neighborhood, there is a need to understand both the integrated and embedded constitution of social innovations, as well as their role and position related to multiple system configurations. This may inform closer ties between 'villages' and all sectoral policies to develop new institutional responses. It may equally result in the rescaling of 'villages' from neighborhood initiatives to vital parts of metropolitan strategies, thus adding a new dimension of empowerment. 
Therefore, in order to drive place-based sustainability transitions, cities need to actively exploit the potentials of emergent forms of conjoint social and governance innovations, decisively leaving the established comfort zones of domain-specific policies, strategic actor networking and conventional forms of 'community participation'. In turn, where the discussed conditions are not well supported, cities are likely to further stabilize prevailing system structures, thus helping to sustain current trends of unsustainability.

\section{Acknowledgements}

The author thanks all interviewees for their kind cooperation, the Seoul Village Community Support Center for providing data, and especially Kyuyoung Han, Kyung A Kim and Junhan Kim for their support through data collection, analysis and translation. This research received no specific grant from any funding agency in the public, commercial, or not-for-profit sectors.

\section{References}

1. UNEP City-Level Decoupling: Urban resource flows and the governance of infrastructure transitions. A Report of the Working Group on Cities of the International Resource Panel. Swilling M., Robinson B., Marvin S. and Hodson M.; United Nations Environment Program: Nairobi, 2013.

2. UN SDSN The Urban Opportunity: Enabling Transformative and Sustainable Development; UN Sustainable Development Solutions Network: Bangalore / New York, 2013.

3. Collier, M. J.; Nedović-Budić, Z.; Aerts, J.; Connop, S.; Foley, D.; Foley, K.; Newport, D.; McQuaid, S.; Slaev, A.; Verburg, P. Transitioning to resilience and sustainability in urban communities. Cities 2013, 32, S21-S28.

4. McCormick, K.; Anderberg, S.; Coenen, L.; Neij, L. Advancing sustainable urban transformation. J. Clean. Prod. 2013, 50, 1-11.

5. Westley, F.; Olsson, P.; Folke, C.; Homer-Dixon, T.; Vredenburg, H.; Loorbach, D.; Thompson, J.; Nilsson, M.; Lambin, E.; Sendzimir, J.; Banerjee, B.; Galaz, V.; Leeuw, S. van der Tipping Toward Sustainability: Emerging Pathways of Transformation. AMBIO 2011, 40, 762-780.

6. Burch, S.; Shaw, A.; Dale, A.; Robinson, J. Triggering transformative change: a development path approach to climate change response in communities. Clim. Policy 2014, 1-21.

7. Næss, P.; Vogel, N. Sustainable urban development and the multi-level transition perspective. Environ. Innov. Soc. Transit. 2012, 4, 36-50.

8. Urbanization in Asia; Wan, G.; Sridhar, K. S., Eds.; Springer: New York, 2013.

9. Coenen, L.; Benneworth, P.; Truffer, B. Toward a spatial perspective on sustainability transitions. Res. Policy 2012, 41, 968-979.

10. Raven, R.; Schot, J.; Berkhout, F. Space and scale in socio-technical transitions. Environ. Innov. Soc. Transit. 2012, 4, 63-78.

11. Marsden, T. Sustainable place-making for sustainability science: the contested case of agri-food and urban-rural relations. Sustain. Sci. 2012, 8, 213-226.

12. Späth, P.; Rohracher, H. Local Demonstrations for Global Transitions-Dynamics across Governance Levels Fostering Socio-Technical Regime Change Towards Sustainability. Eur. Plan. Stud. 2012, 20, 461-479. 
13. Bridge, G.; Bouzarovski, S.; Bradshaw, M.; Eyre, N. Geographies of energy transition: Space, place and the low-carbon economy. Energy Policy 2013, 53, 331-340.

14. Murphy, J.; Smith, A. Understanding transition-periphery dynamics: renewable energy in the Highlands and Islands of Scotland. Environ. Plan. A 2013, 45, 691 - 709.

15. Mans, U. Tracking geographies of sustainability transitions: Relational and territorial aspects of urban policies in Casablanca and Cape Town. Geoforum 2014, 57, 150-161.

16. Hodson, M.; Marvin, S. Can cities shape socio-technical transitions and how would we know if they were? Res. Policy 2010, 39, 477-485.

17. Monstadt, J. Conceptualizing the political ecology of urban infrastructures: insights from technology and urban studies. Environ. Plan. A 2009, 41, 1924-1942.

18. Berkhout, F.; Verbong, G.; Wieczorek, A. J.; Raven, R.; Lebel, L.; Bai, X. Sustainability experiments in Asia: innovations shaping alternative development pathways? Environ. Sci. Policy 2010, 13, 261-271.

19. Bulkeley, H.; Castán Broto, V.; Maassen, A. Governing urban low carbon transitions. In Cities and Low Carbon Transitions; Routledge: New York, 2011; pp. 29-41.

20. Geels, F. W. Technological transitions as evolutionary reconfiguration processes: a multi-level perspective and a case-study. Res. Policy 2002, 31, 1257-1274.

21. Shaping urban infrastructures: intermediaries and the governance of socio-technical networks; Guy, S.; Marvin, S.; Medd, W.; Moss, T., Eds.; Earthscan: London ; Washington, DC, 2011.

22. Bulkeley, H.; Castán Broto, V.; Edwards, G. An urban politics of climate change: experimentation and the governing of socio-technical transitions; Routledge: Abingdon, Oxon ; New York, NY, 2014.

23. Loorbach, D. Transition Management for Sustainable Development: A Prescriptive, ComplexityBased Governance Framework. Gov. Int. J. Policy Adm. Inst. 2010, 23, 161-183.

24. Hodson, M.; Marvin, S. Mediating Low-Carbon Urban Transitions? Forms of Organization, Knowledge and Action. Eur. Plan. Stud. 2012, 20, 421-439.

25. Hamann, R.; April, K. On the role and capabilities of collaborative intermediary organisations in urban sustainability transitions. J. Clean. Prod. 2012, 50, 12-21.

26. Hodson, M.; Marvin, S.; Bulkeley, H. The Intermediary Organisation of Low Carbon Cities: A Comparative Analysis of Transitions in Greater London and Greater Manchester. Urban Stud. 2013, 50, 1403-1422.

27. Seyfang, G.; Smith, A. Grassroots innovations for sustainable development: Towards a new research and policy agenda. Environ. Polit. 2007, 16, 584-603.

28. Shove, E.; Walker, G. Governing transitions in the sustainability of everyday life. Res. Policy 2010, $39,471-476$.

29. Smith, A.; Seyfang, G. Constructing grassroots innovations for sustainability. Glob. Environ. Change 2013, 23, 827-829.

30. Kemp, R.; Schot, J.; Hoogma, R. Regime shifts to sustainability through processes of niche formation: The approach of strategic niche management. Technol. Anal. Strateg. Manag. 1998, 10, 175-198.

31. Bai, X.; Roberts, B.; Chen, J. Urban sustainability experiments in Asia: patterns and pathways. Environ. Sci. Policy 2010, 13, 312-325. 
32. Seyfang, G.; Haxeltine, A. Growing grassroots innovations: Exploring the role of community-based initiatives in governing sustainable energy transitions. Environ. Plan. C Gov. Policy 2012, 30, 381400.

33. Davies, A. Enterprising Communities: Grassroots Sustainability Innovations; Advances in Ecopolitics; Emerald: Bingley, U.K., 2012.

34. Can neighbourhoods save the city?: community development and social innovation; Moulaert, F.; Swyngedouw, E.; Martinelli, F.; González, S., Eds.; Routledge: London, 2010.

35. Social innovation and territorial development; MacCallum, D.; Moulaert, F.; Hillier, J.; Vicari Haddock, S., Eds.; Ashgate: Farnham, England; Burlington, VT, 2009.

36. Moulaert, F.; MacCallum, D.; Mehmood, A.; Hamdouch, A. General introduction: the return of social innovation a scientific concept and social practice; Moulaert, F.; MacCallum, D.; Mehmood, A.; Hamdouch, A., Eds.; Edward Elgar: Cheltenham, 2013.

37. Mulugetta, Y.; Jackson, T.; van der Horst, D. Carbon reduction at community scale. Energy Policy 2010, 38, 7541-7545.

38. Aylett, A. Networked urban climate governance: neighborhood-scale residential solar energy systems and the example of Solarize Portland. Environ. Plan. C Gov. Policy 2013, 31, 858-875.

39. Holling, C. S. Resilience and stability of ecological systems. Annu. Rev. Ecol. Syst. 1973, 4, 1-23.

40. Navigating social-ecological systems : building resilience for complexity and change; Berkes, F.; Colding, J.; Folke, C., Eds.; Cambridge University Press: Cambridge, 2003.

41. Ernstson, H.; Leeuw, S. E. van der; Redman, C. L.; Meffert, D. J.; Davis, G.; Alfsen, C.; Elmqvist, T. Urban Transitions: On Urban Resilience and Human-Dominated Ecosystems. AMBIO 2010, 39, 531-545.

42. Wilson, G. A. Community resilience, globalization, and transitional pathways of decision-making. Geoforum 2012, 43, 1218-1231.

43. Beilin, R.; Wilkinson, C. Introduction: Governing for urban resilience. Urban Stud. 2015, 52, $1205-$ 1217.

44. Folke, C. Resilience: The emergence of a perspective for social-ecological systems analyses. Glob. Environ. Change 2006, 16, 253-267.

45. Walker, B.; Holling, C. S.; Carpenter, S. R.; Kinzig, A. Resilience, Adaptability and Transformability in Social-ecological Systems. Ecol. Soc. 2004, 9, 5.

46. Olsson, P.; Bodin, Ö.; Folke, C. Building Transformative Capacity for Ecosystem Stewardship in Social-Ecological Systems. In Adaptive Capacity and Environmental Governance; Armitage, D.; Plummer, R., Eds.; Springer Berlin Heidelberg: Berlin, Heidelberg, 2010; pp. 263-285.

47. Wilson, S.; Pearson, L. J.; Kashima, Y.; Lusher, D.; Pearson, C. Separating Adaptive Maintenance (Resilience) and Transformative Capacity of Social-Ecological Systems. Ecol. Soc. 2013, 18.

48. WRI Total GHG Emissions Excluding Land-Use Change and Forestry Per Capita http://cait2.wri.org (accessed Dec 8, 2014).

49. Seoul Institute 서울특별시 마을공동체 기본 계획(Seoul village community basic plan); Seoul: Seoul Institute, 2012.

50. Abdallah, S.; Michaelson, J.; Shah, S.; Stoll, L.; Marks, N. The Happy Planet Index: 2012 Report. A global index of sustainable well-being; nef: London, 2012. 
51. Social Watch Measuring Inequity: The 2012 Gender Equity Index http://www.socialwatch.org/node/14367.

52. Värnik, P. Suicide in the World. Int. J. Environ. Res. Public. Health 2012, 9, 760-771.

53. Gelézeau, V. Séoul, ville géante, cités radieuses; Collection Asie orientale; CNRS éditions: Paris, 2003.

54. Lee, S.-H.; Hwang, J. 도시재생의 정책 배경과 패러다임의 전환 (Urban Regeneration, its Political Background and New Paradigm shift). J. Korea Plan. Assoc. 2013, 48, 387-410.

55. Park, C. 아파트 공적 냉소와 사적 정열이 지배하는 사회 (Apartment); Mati: Seoul, 2013.

56. KISS 무주군 진도리 생태마을 기본계획 (Muju-Gun Jindo-ri eco village basic plan); 1998.

57. Green Korea United 생태마을 지침서 (Eco village guidance); aa, 1998.

58. Yu, C. B. 우린 마을에서 논다 (We have fun in the village); 또 하나의 문화: 서울, 2010.

59. Wi, S. N. 마을하기, 성미산마을의 역사와 생각 (The history and thinking of Seongmisan village); Seoul: Korea Research Institute for Human Settlements (KRIHS), 2013.

60. $\mathrm{SMG}$ 서울특별시 마을공동체 만들기 지원 등에 관한 조례 (Building a village community in Seoul); 2012; Vol. 5262.

61. SMG 2013 희망서울 시정운영계획 (2013 Hee-mang Seoul plan) 2013.

62. SMG One less nuclear power plant. Phase 2. Seoul sustainable energy action plan.; Seoul: Seoul Metropolitan Government, 2014.

(C) 2015 by the authors; licensee MDPI and IFoU, This article is an open access article distributed under the terms and conditions of the Creative Commons Attribution license. 